\title{
Benchmarking Water Use in the UK Food and Drink Sector: Case Study of Three Water-Intensive Dairy Products
}

\author{
Ikenna Ajiero $^{1}$ - David Campbell ${ }^{2}$
}

Received: 17 November 2016/Revised: 16 October 2017 / Accepted: 22 October 2017 / Published online: 25 November 2017

(C) The Author(s) 2017. This article is an open access publication

\begin{abstract}
There is an established body of research on water use by the domestic and agricultural sectors, but very little peer-reviewed literature have been published on industrial water use. This has been attributed to the commercially competitive and complex nature of the industrial sector, and the attendant difficulties in collecting requisite data for any analysis (Reynaud, 2003). Consequent upon this, there is a growing concern over the sustainability of water-related industrial practices and processes. To this end, focusing on key waterintensive industrial subsectors, the food and drink sector which according to DEFRA (2007) and the Environment Agency 2013 has the highest rate of water use in the industrial sector, was chosen for this performance assessment, the aim being to clearly understand how various food and drink firms use water, relative to other "comparable" firms, and against industry standards or benchmarks. For the analyses, data on water use were collected from 53 dairy companies, for a 5year (minimum) period, and covering three water-intensive dairy products-liquid milk, butter and cheese. Thus, data were collected from 27 liquid milk-producing companies, 13 butter- and 13 cheese-processing companies. Based on the findings, of the 53 benchmarked companies, 17 companies' water use performance were ranked "excellent"; 26 companies, "average"; while the remaining 10 companies"
\end{abstract}

Ikenna Ajiero

reginaldikenna@uniuyo.edu.ng

David Campbell

d.p.campbell@hw.ac.uk

1 University of Uyo, Uyo, Akwa Ibom State, Nigeria

2 School of the Built Environment, Heriot Watt University, Scotland, UK performance were "poor". These results emphasise the need for creation of more comprehensive water management schemes and conservation clubs within the food and drink sector. From this study, benchmarking, a performance assessment and improvement process, has been established as a veritable strategy for driving behavioural change in water use by industry, and enhancing the sustainability credential of the UK industrial sector, in terms of fresh water use.

Keywords Company $\cdot$ Benchmark $\cdot$ Sector

\section{Introduction}

The UK industry greatly depends on water for its varied processes and productions. Water use in the industrial sector includes the extractive (or off-river), for manufacturing, as raw material, heat sink or coolant, solvent and mining, and nonextractive (or in-river), such as hydro energy production and disposal of industrial effluents [48]. Although, several regulations exist to frame the practices in the freshwater use, but for a holistic solution to the exacerbating water issues in the UK to be achieved, the driver should be sustainability. This involves encouraging all water users to go beyond compliance and stimulate sustainable practices throughout the water use process cycle [40]. This ethos may be considered as the rationale behind the Food Industry Sustainability Strategy (FISS), which in a bid to encourage optimal water use in the industry, challenged UK food industry to reduce its levels of water usage by setting an overall water reduction target of $20 \%$ by 2020, against a 2007 baseline [18].

Generally, industry requires high volumes of water for its processes; more even, in the food and drink sector, water of very high quality is required to ensure that no health standard is compromised. According to the ([25], p.7), "Water use for 
food and drink manufacture represents $56 \%$ of total water use by the industry". Water conservation in the food and drink sector is thus considered important, as it constitutes an area of potential water and financial savings in the industrial arena. As asserted by the ([30], p.16):

“... As water is a key part of the manufacturing process, in times of shortage where supplies are threatened, its value may become much higher than its nominal cost. Nonetheless, a $20 \%$ reduction in water use could save the food manufacturing industry $£ 60$ million a year”.

When aggregated, water use by industry remains relatively large; however, water demand varies from one industrial sector and process to another. With the industry's varied processes across a range of subsectors, an effective way of achieving water saving is through performance assessment using water use per unit of each product [53]. Such data enable comparison of performance across organisations, against set benchmarks WRAP, 2014. However, it suffices to state that water use data per unit of product for different organisations generally vary and are often both site and country-specific. Major reasons for such variations in water use per product include the technology in use, availability of the water resource and the original state of the raw material used for specific processes. Table 1 reveals water usage per unit product in selected European Union countries; albeit, variations in data collection mode remain inexcusable, but the values shown in the table support the argument that even among developed countries, there are great prospects of water minimisation per unit product of industrial processes.

From Table 1 above, it is striking how $1 \mathrm{~L}$ of milk is produced using $5 \mathrm{~L}$ of water in Austria while the same volume of milk is produced using less than one third of Austria's $5 \mathrm{~L}$, in countries like Sweden and Norway. Also, $1 \mathrm{~kg}$ of steel which is manufactured in the UK with $100 \mathrm{~L}$ of water is also manufactured in Sweden using 0.6-5.3 L of water. Apparently, potentials for significant water savings exist in different countries depending on the water intensities of their processes and products, and relative to those of other countries.

Focusing on the UK, the ([17], p.65) estimates that:

"The British food industry alone consumes approximately 900 megalitres of water each day, enough to supply almost three-quarters of all customers' needs in London daily".

Further, despite the stringent regulatory provisions on wastewater discharge, with the ever-advancing technological drive and industrialization of the UK, the degree of industrial effluent pollution has recently intensified. Food industries discharge wastewater mixed with high concentration of fat, oil and grease (FOG) that end up clogging the sewers and resulting in heavy sums for maintenance of these channels. Chemical plants discharge highly insoluble and nonbiodegradable toxins as wastewater; the iron and steel sector discharges heavily metal-polluted wastewater, while nuclear plants discharge water containing traces of radioactive elements, biocides and nano-nuclides that form very complex compounds in the wastewater plants [28]. Unfortunately, most of these contaminants do not get entirely removed at the treatment plants and in adverse cases, where treatment plants overflow, the wastewater and its teeming pollutants are discharged directly into receiving streams [19].

A comprehensive investigation on water-intensive processes in the UK was conducted by [17]. The report of this assessment presented a generalised estimate of average water use by major industrial sectors annually (see Table 2). It can be seen from the table that food and drink sector alone averagely uses the available fresh water in the UK to the tune of 307 million $\mathrm{m}^{3} /$ year. This ranks food and drink sector as the highest water user in the industrial arena, closely followed by the chemical manufacture sector.

From the foregoing, it is thus imperative to further study the food and drink sector, in order to understand how it uses the freshwater resource for its process.

\section{Water Use in the UK Food and Beverages (Drink) Sector}

Water plays a very significant role in the food- and beveragemanufacturing processes; it is used for a wide range of activities such as transporting, cleaning, washing, processing, blanching, formulating products, peeling, mixing, steam generation, freezing and for purposes of hygiene. In 2013, WRAP's technical analysis revealed that the food and drink manufacturing alone uses about 190 million $\mathrm{m}^{3}$ of water per year, of which 78 million $\mathrm{m}^{3}$ is directly abstracted [64].

A key peculiarity associated with the food and beverage sector's water demand is the high quality of water required for its processes. In order to meet regulatory standards and ensure the manufacture of hygienic products, the food and beverage sector heavily relies on mains water for most of its water needs. However, in the past decade, there has been a decline in mains water use in this sector and a rise in water abstraction from rivers and underground sources. This has been attributed to the high and growing cost of purchasing water from water companies [59].

\section{Water Use in the Food Processing Sector}

Majority of water used in the food processing industry is for washing of food, pasteurisation, cleaning of equipment, food preparation (cooking), steaming and sterilisation; or as an 
Table 1 Water usage per unit product in selected European Union countries

\begin{tabular}{|c|c|c|c|c|c|c|}
\hline Country & $1 \mathrm{~L}$ of beer & $\begin{array}{l}1 \mathrm{~L} \text { of } \\
\text { milk }\end{array}$ & $1 \mathrm{~kg}$ of cloth & $\begin{array}{l}1 \mathrm{~kg} \text { of } \\
\text { paper }\end{array}$ & $\begin{array}{l}1 \mathrm{~kg} \text { of } \\
\text { steel }\end{array}$ & $1 \mathrm{~kg}$ of sugar \\
\hline Austria & 10 & 5 & $\mathrm{n} / \mathrm{d}$ & 150 & 15 & 15 \\
\hline Denmark & 3.4 & & & & & \\
\hline France & 25 & $1-4$ & $\mathrm{n} / \mathrm{d}$ & $250-500$ & $300-600$ & $21-35$ \\
\hline Ireland & 8 & & & & 4.5 & \\
\hline Norway & 10 & $1-1.5$ & 130 (all kinds) & 20 & 30 & $\mathrm{n} / \mathrm{d}$ \\
\hline Spain & $6-9$ & $1-5$ & 8-20 (wool) & 250 & 30 & $3.5-5$ \\
\hline Sweden & $3-5$ & 1.3 & $40-50$ & 20 & $0.6-5.3$ & 0.5 \\
\hline UK & $\begin{array}{c}6.5 \text { (estimated } \\
\text { range } 2-10)\end{array}$ & 2.9 & $\begin{array}{l}\text { 6-300 (depends on the } \\
\text { type of fabric) }\end{array}$ & $15-30$ & 100 & $\begin{array}{l}1.5 \text { (estimated } \\
\quad \text { range } 0.7-6 \mathrm{~L} \text { ) }\end{array}$ \\
\hline
\end{tabular}

Source: [28]

$n / d$ no data

additive or stabiliser in canned fruit or vegetable [16]; these activities constitute process water and are areas of potential water conservation. As shown in Fig. 1, process water accounts for the largest water use in the food sector (31\%).

Although Fig. 1 reveals the most water-intensive processes in the food manufacturing sector, but different food products require unique water quantities for their specific tasks and these vary significantly. In producing sugar, it has been discovered that about half of the intake water is basically used for cooling, while about $20 \%$ or less is actually used for processing [22]. In contrast, "for meat processing and fruit preservation, about $60 \%$ of the intake water is used as process water" ([16], p.89).

\section{Water Use in Beverage-Manufacturing Processes}

A key step towards any water conservation initiative in the beverage industry requires a good understanding of waterintensive processes of each product. As noted by Environment Agency [24], water use percentages for equipment preparation in bottled water and fruit juice production are 67 and 51\%, respectively; whereas, in the case of carbonated soft drinks, $78 \%(>3 / 4)$ of the total water used in manufacturing the product is process water. These waterintensive areas have potentials for the greatest water

Table 2 The UK annual water use by major industrial sectors

\begin{tabular}{ll}
\hline Sector & Annual water use - millions $\mathrm{m}^{3}(\mathrm{t})$ \\
\hline Food and drink processing & 307 \\
Chemicals & 273 \\
Electronics & 241 \\
Paper and board & 155 \\
Plastic and rubber & 83 \\
Textiles and leather & 63 \\
\hline
\end{tabular}

Adapted from [17] conservation and should be the main target of any water reduction strategy. Thus, there is the prevailing need to identify possible means of saving water in food and drink processes, and benchmarking is considered a veritable tool for this exercise. Application of benchmarking to improve on performance in water use is usually obtained at a comparatively low cost, yet its water, energy and financial benefits or merits are always significant. Metric benchmarking leads to volumetric reduction in industrial water consumption, while process benchmarking helps to identify the best water business practices.

It is pertinent to state that the need to benchmark the UK's industrial sector's freshwater use became heightened following the unusual increase in industrial water use in the UK by 37\% between 1991 and 1995 [7]. Further, researches by [32], Atimtay and Subhas [5] and Suvio [56] revealed that industrial processes, practices and systems have been subjected to increasing stringent environmental regulations, particularly given industry's intensive freshwater abstractions and wastewater discharge. As reported by WRAP in 2012, the dairy industry took up $21 \%$ of the entire freshwater use by the UK food and

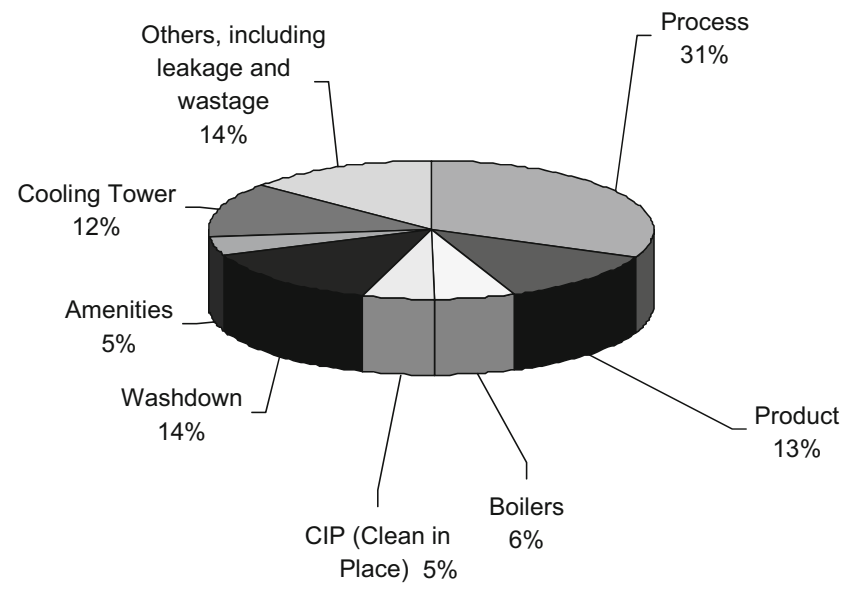

Fig. 1 Water use breakdown in a typical food manufacturing sector. Source: Ellis et al. [22] 
drink sector and ranked the highest [58]; whereas, in 2013, although the diary sector's water use reduced to $17 \%$ and was at par with the water use percentage for meat processing, this percentage was still the highest in the food and drink sector [29]. Thus, this study focuses on the dairy sector, with the aim of assessing the water use rates (per unit of product) of various dairy subsectors.

\section{Water Use in the Dairy Industry}

According to [61], the dairy industry can be defined as a major industry in the food and beverage sector that principally produces milk on farm for human consumption, through keeping of mainly cows and also goats and sheep; and also processes milk, with the objective of prolonging its saleable life. This aspect of processing milk is often achievable through heating the milk to the point where it can be kept longer and still remain safe for human consumption or processing the milk product by dehydration or semi-dehydration to form milk powder, butter or hard cheese, thereby extending its keeping quality.

Given her approximately 14 billion litres of annually produced liquid milk, the UK is ranked the third largest milk producer among the European Union states, after Germany and France, and the tenth largest producer in the world [6]. However, with a 2.91 requirement of water for each litre of raw milk produced [28], it is apparent that the dairy industry uses huge volumes of water for its milk production, a good percentage of which can be conserved with proper management strategies.

Water of high quality is an indispensable resource in any dairy farm; its use in the dairy sector includes for drinking, cleaning, and cooling. Although, even as dairy farms need water for majority of its processes, drivers such as the everincreasing cost of water, more stringent regulatory regimes and high cost of energy for pumping and processing of milk have made it increasingly essential to optimally use water in the dairy industry.

As noted by the Department of Environmental Science and Technology [20] and the Agriculture and Horticulture Development Board [1], three water types are associated with the dairy system; these include green, blue and grey water. Green water covers water from precipitation-rain, snow, sleet, hail etc.; blue water is water from renewable water sources such as lakes, rivers, and groundwater or water that is treated to drinking water standard, for cleaning or use as process water; lastly, grey water in dairy processes is water used for cleaning dairy parlours, equipment etc. Water use in the dairy sector is associated with three systems: the feed, the livestock and process systems. Water used to grow forage or grass is considered as virtual water which is supplied by the feed system directly into the fields or livestock system. The livestock system uses water for growing the livestock; whereas, the process system involves water for processing the products. Based on these descriptions, it is clear that water used in the feed system is mainly the virtual water which in this case is the green water. The livestock system combines both the green and blue water for its processes, while process system thus depends on the blue water for the purpose of hygiene [20].

It is also noteworthy that relative to the brewing industry's $70-80 \%$ use of process water (water in product), cleaning activities account for about $70 \%$ of water use in the dairy sector $[26,47]$. Yet, by improving water use efficiency, water and wastewater bills could be reduced by $30 \%$; this could be increased by $50 \%$ through a "more efficient planning, applying new technology and proper benchmarking" ([47], p.2). In order to understand how an organisation is performing, it is essential that such organisation is benchmarked against industry standards (best practice) or/and comparable organisations. A typical example of this comparison is seen in Table 3. The table shows average water consumption rates for dairy products against their corresponding best practice values. It can be seen from the table that the average water use for skimmed milk is $3.6 \mathrm{~m}^{3} / \mathrm{t}$; whereas, the best practice water consumption is $2.1 \mathrm{~m}^{3} / \mathrm{t}$. Also, in butter production, typical water use ranges from $1.5-6.7 \mathrm{~m}^{3} / \mathrm{t}$, while the benchmark or best practice value is $1.3 \mathrm{~m}^{3} / \mathrm{t}$. Comparing these values clearly reveals great potentials for water savings in each milk process.

\section{Historical Antecedents of Benchmarking Globally}

The concept or process of benchmarking was first applied by Rank Xerox in 1979 [15]. As noted by ([57], p.6) and ([38], p.2), "benchmarking was pioneered by the Xerox Corporation" in 1979 as a part response to the global "competition in the photocopier market", and became widely used in the US corporations in the 1980s as means of competing favourably in the global market which was then prone to deregulations.

Consequently, Rank Xerox's application of process benchmarking as highlighted by Camp [14] and Spendolini ([55], cited in [36]) heralded the popularity of the benchmarking concept and adoption of benchmarking by different sectors of industries, organisations and businesses, as a performance assessment method and total quality management (TQM) tool. Kelessidis [38] acknowledged that Xerox benchmarks approximately 240 performance elements in contemporary times, against the relatively limited elements they benchmarked years ago.

Further, the European Foundation for Quality Management (EFQM), comprising of over 800 multinational and national companies, is an organisation founded in 1988 to provide key strategic framework for promoting TQM and achieving global competitive advantage in business processes. Also, the 
Table 3 Typical and optimal water use by major dairy products

\begin{tabular}{|c|c|c|c|c|c|}
\hline \multicolumn{2}{|c|}{ Type of product } & \multirow{2}{*}{$\begin{array}{l}\text { Units } \\
\mathrm{m}^{3} / \mathrm{t}\end{array}$} & \multirow{2}{*}{$\begin{array}{l}\text { Water } \\
\text { or } \\
\text { steam }\end{array}$} & \multirow{2}{*}{$\begin{array}{l}\text { SWC (specific water } \\
\text { consumption) average/ } \\
\text { range }\end{array}$} & \multirow{2}{*}{$\begin{array}{l}\text { SWC (specific water } \\
\text { consumption) best } \\
\text { practice }\end{array}$} \\
\hline Milk & Milk plant & & & & \\
\hline & & $\mathrm{m}^{3} / \mathrm{t}$ & Water & $0.192^{1,2,3}$ & \\
\hline & $\begin{array}{l}\text { Pasteurised milk- } \\
\text { bulk average }\end{array}$ & $\mathrm{m}^{3} / \mathrm{m}^{3}$ & Water & $1.6^{4}$ & $0.75^{4}$ \\
\hline & $\begin{array}{l}\text { Pasteurised milk- } \\
\text { bulk } \\
\quad<1000 \mathrm{~m}^{3} / \text { month }\end{array}$ & $\mathrm{m}^{3} / \mathrm{t}$ & Water & $3.2^{4}$ & \\
\hline & $\begin{array}{l}\text { Pasteurised milk- } \\
\text { bulk } \\
\quad>1000 \mathrm{~m}^{3} / \text { month }\end{array}$ & $\mathrm{m}^{3} / \mathrm{t}$ & Water & $1^{4}$ & \\
\hline & $\begin{array}{l}\text { Pasteurised milk- } \\
\text { sachets }\end{array}$ & $\mathrm{m}^{3} / \mathrm{m}^{3}$ & Water & $1.7^{4}$ & $1.1^{4}$ \\
\hline & $\begin{array}{l}\text { Pasteurised milk- } \\
\text { cartons }\end{array}$ & $\mathrm{m}^{3} / \mathrm{m}^{3}$ & Water & $2.2^{4}$ & $1.5^{4}$ \\
\hline & $\begin{array}{l}\text { Pasteurised milk- } \\
\text { bottles }\end{array}$ & $\mathrm{m}^{3} / \mathrm{m}^{3}$ & Water & $3^{4}$ & $2^{4}$ \\
\hline & Skimmed milk & $\mathrm{m}^{3} / \mathrm{t}$ & Water & $3.6^{4}$ & $2.1^{4}$ \\
\hline & Condensed milk & $\mathrm{m}^{3} / \mathrm{m}^{3}$ & Water & $4.4^{4}$ & $3.5^{4}$ \\
\hline & $\begin{array}{l}\text { Sterilised/UHT } \\
\text { products }\end{array}$ & $\mathrm{m}^{3} / \mathrm{m}^{3}$ & Water & $3.7^{\mathrm{a} 4}$ & $2^{\mathrm{a} 4}$ \\
\hline \multirow{2}{*}{\multicolumn{2}{|c|}{ Powdered milk }} & $\mathrm{m}^{3} / \mathrm{t}$ & Water & $0.03^{1,2,3}-11.8^{4}$ & $8.7^{4}$ \\
\hline & & $\mathrm{m}^{3} / \mathrm{t}$ & Steam & $0.091^{1,2,3}$ & \\
\hline \multirow{2}{*}{\multicolumn{2}{|c|}{ Blue cheese }} & $\mathrm{m}^{3} / \mathrm{t}$ & Water & $11.29^{1,2,3}$ & \\
\hline & & $\mathrm{m}^{3} / \mathrm{t}$ & Steam & $0.353^{1,2,3}$ & \\
\hline \multirow{3}{*}{\multicolumn{2}{|c|}{ Cheese }} & $\mathrm{m}^{3} / \mathrm{t}$ & Water & $8.5^{1,2,3}-23^{4}$ & $20^{4}$ \\
\hline & & & & $9.1^{6}$ & \\
\hline & & & Steam & $0.25^{1,2,3}$ & \\
\hline \multicolumn{2}{|c|}{ Whey } & $\mathrm{m}^{3} / \mathrm{t}$ & Water & $8.3^{6}$ & \\
\hline \multicolumn{2}{|c|}{ Ice cream } & $\mathrm{m}^{3} / \mathrm{t}$ & Water & $0.88-2.5^{\mathrm{a} 4}$ & $1.9^{\mathrm{a} 4}$ \\
\hline \multirow{3}{*}{\multicolumn{2}{|c|}{ Yoghurt }} & $\mathrm{m}^{3} / \mathrm{t}$ & Water & $4.24^{1,2,3}$ & \\
\hline & & $\mathrm{m}^{3} / \mathrm{t}$ & Steam & $0.135^{1,2,3}$ & \\
\hline & & $\mathrm{m}^{3} / \mathrm{m}^{3}$ & Water & $10.2^{\mathrm{a} 4}$ & $6.3^{\mathrm{a} 4}$ \\
\hline \multicolumn{2}{|c|}{ Butter } & $\mathrm{m}^{3} / \mathrm{t}$ & Water & $1.5^{\mathrm{a} 4}-6.7^{6}$ & $1.3^{\mathrm{a} 4}$ \\
\hline
\end{tabular}

${ }^{\text {a }}$ An additional average specific water consumption (SWC) of 0.6 is be added to account for intermediate products' water use

Adapted from ${ }^{1}$ Harris. D. [31]; ${ }^{2}$ North Carolina Cooperative Extension Service. [44]; ${ }^{3}$ Bartholomai, A. [8]. ${ }^{4}$ Steffen, Robertson and Kirsten Inc., Consulting Engineers, [50]; ${ }^{5}$ ETBPP [27]; ${ }^{6}$ Environment Agency [23] cited in ([24], p. 11)

Benchmarking Co-ordination Office (BCO) instituted in 1997 by the European Commission which is presently managed by the Irish Productivity Centre provides robust benchmarking resource database and promotes benchmarking as a tool for improving market competitiveness and standard of living in Europe [38].

Suffice it that the UK Quality Award of 1994 which followed the European Quality Award of 1992 heralded the prominence of benchmarking in the UK [54]. Currently in the UK, the Confederation of British Industries (CBI) provides manufacturing databases for on-line assessment of practices and performance of the manufacturing companies [38]. It is also important to highlight that benchmarking of the UK water utilities has got a legal backing, as it is expressly legislated for in section 34(3) of the Water Act, 1991,which asserts that: "the number of water enterprises which are under independent control ... to make comparisons between different such water enterprises"[60].

\section{Overview of Benchmarking Efforts in the Water Sector}

Numerous countries now conduct benchmarking on their water utilities for different purposes. As conceded by Larsson et al. [42], Australia developed the "syndicate benchmarking" to help councils understand how best to apply benchmarking to their water processes, and America Water Works 
Association conducted benchmarking on Philadelphia water with the aim of gaining knowledge on how to apply the process benchmarking for optimal performance improvement. Accordingly, countries like Canada, Netherlands, Mexico, Hong Kong, Italy and Poland have conducted benchmarking on their water processes with varying goals such as improvement on water and service quality, transparency and efficiency boost up, and enhancement of overall competitiveness of their water industries. In the UK, OFWAT examined levels of changes in different water undertakings using the comparative efficiency assessment (CEA) method [42].

It is also worth stating that over the years beginning from 2000, Scottish Water has been using benchmarking to assess its performance, relative to those of England and Wales water utilities; the areas of assessment according to Scottish Water include service levels, operating expenditure, capital maintenance and enhancement [52].

In what is considered as fundamentals of benchmarking application, Camp [14] captured the universally adopted Xerox's 10-step benchmarking model which serves as basics for designing contemporary benchmarking methodologies in water utilities. They include:

1) Decide what to benchmark

2) Establish the team

3) Identify benchmarking elements

4) Identify internal data sources and methods of collection

5) Collect internal data

6) Decide external benchmarking partners

7) Collect external data

8) Analyse results and refine gap

9) Adjust goals and develop improvement plan

10) Review and re-benchmark

However, Love et al. [43] have added that even as the 10step benchmarking model serves as an excellent outline for benchmarkers to follow, there is a pressing need to undergo intensive training on the subject, in order to clearly understand these steps.

Whereas, it is currently widely utilised in Europe, Australia, Asia and in almost all public service sectors to improve productivity, benchmarking as a concept, process or practice has become a household name in utility performance measurement and improvement, both in the water industry and other infrastructure regimes. As conceded by [45], benchmarking "has become one of the buzzwords of this decade and has gained popularity in many industries including public utility organisations" ([39], p.1). However, notwithstanding its popularity, many organisations are hitherto yet to identify with the significance of benchmarking in enhancing their water productivity or performance.

\section{Definitions of Benchmarking}

One of the major objectives of every benchmarking study is to provide a clear and comprehensive definition of benchmarking in order to elucidate the concept and enhance the understanding of its application as a performance improvement tool. According to ([57], p.2), benchmarking is a process of a deliberate self-evaluation process through structured and systematic activities designed to discretely reveal "better and smatter ways" of self-improvement and self-regulation. The source further notes that "It works best as part of a culture of constantly seeking out quality and performance improvement"([57], p.2).

It is essential to note that the meaning of benchmarking should comprise of both qualitative and quantitative or numeric scrutiny, as a tilt towards one aspect will not give a comprehensive explanation of the benchmarking concept. On this note, an encompassing definition of benchmarking was proposed by ([9], p.14) as "... any beneficial reduction in water use or in water loss". It is noted by the author that the "beneficial" implies that "the reduction in water use should give rise to a net increase in social welfare provided, where the resources used have a lesser value than those saved". These both depict the relevance of economic efficiency and underpin the significance of process benchmarking.

From the foregoing, even where a benchmarked organisation recognises itself as high performing, the substance of benchmarking remains that it must be considered as a learning process.

\section{Types of Benchmarking}

In principle, benchmarking types are considered distinct activities, capable of being singly adopted and applied, but in practice, most benchmarking activities involve a combination of different performance evaluation aspects that actually underscore and frame the classification of the benchmarking types. A comprehensive summary of benchmarking types is posited by Camp [14]; Jackson [34]; Jackson [35]; Spendolini [55]; Price [46]; Alstete [3]; Schofield [51]; Appleby [4]; Jackson and Lund [37], cited in [36] as follows: metric; process; brokered; regulatory; competitive; international; generic; explicit; implicit; independent; collaborative; vertical and horizontal; external; internal; functional; regulatory; international and financial. Of these, the popular types are the metric and process benchmarking.

\section{Metric Data Benchmarking}

Simply known as metric benchmarking, this involves an assessment of the quantitative (numeric) information of an organisation. Historically, metric benchmarking emerged out of the need to measure the numeric indicators of inputs and 
outputs associated with business and industrial activities [36]. This measurement requirement is achieved through the use of performance indicators (PI) and metric benchmarks that are widely published by commercial institutions in the form of league tables. The IBNET toolkit is one benchmarking scheme that comprises of key performance indicators (KPIs) developed for metric assessment.

Suffice it that metric benchmarking helps in identifying areas where there are apparent performance gaps but does not essentially give "an understanding of explanatory factors" ... such as physical traits, geography (location), weather, custom, extenuating factors, population, etc. [36]. Equally, in the opinion of ([39], p.270), "the quality of raw water, the topography of the area and the scale of the operation, all impact on cost to different degrees and are outside the control of management ... these are referred to as explanatory factors." Metric benchmarking focuses on comparing KPIs; this method according to [13] is still the assessment method used by OFWAT and a majority of water industry regulators around the world.

By using numeric values for comparison, metric benchmarking results are adjudged quantitative and precise, but numeric data in one organisation are seldom put together in the same way in other organisations. Thus, figures differ from one company to the other and may not reflect the true level of an organisation's performance efficiency relative to those of others. Reasons for numeric differences may include effects of the operating environment, an organisation's level of technological advancement, dedicated staff expertise, and data collection and/or storage methods in use. On this premise, [39] posits that metric benchmarking basically gives a sense of relative performance. It is important to state that though metric benchmarking is considered very useful for analysis of quantitative data, there are major challenges associated with its application. These, according to Cabrera Jr. et al [12], include the challenge of finding comparable partners or suitable performance indicators and variation(s) in the units of data collected from organizations to be benchmarked.

\section{Process Benchmarking}

Converse to the metric benchmarking approach which is objective and quantitative in nature, the process benchmarking relies greatly on textual (text-based) information. This entails comparing the qualitative or non-numeric activities of an organisation to those of high-performing peer(s), and requires explicit reference to textual facts such as industry bests, specifications, benchmarks and codes of practice for its application [36].

It is noteworthy that process benchmarking, also known as "Xerox style" [39] or simply: Xerox benchmarking, compares the processes and practices of selected peers. As claimed by ([63], p.3), it is "a normative tool with which one utility can compare the effectiveness of its processes and procedures for carrying out different functions to those selected peers."
Process benchmarking according to [42] involves mapping the operations and functions of an organisation to be benchmarked; identifying high-performing organisations, why they are performing so and which aspects constitute their areas of strength; and lastly, adopting or adapting (with amendments) considered best practices by the benchmarked organisation.

\section{Composition of a Typical Benchmarking Strategy: Benchmarks and Key Performance Indicators}

\section{Benchmark Development}

Benchmark as a term was originally applied in surveying to mean a survey peg, datum or mark, normally as a permanent reference point against which levels of various topographic features of the earth can be readily measured $[11,36]$. This concept later gained prominence in the social sciences as a yardstick for measuring performance through comparison. Numerous authors have reckoned with the idea of benchmarks denoting criterion or reference or mark of distinction in products or even best practices or services ([57]; [11, 36]). These reference points according to ([11], p.4) can either be based on targets, averages or percentiles of any set performance or even policy-driven objectives like the "net zero carbon".

Hence, a benchmark is a predefined value used for measuring a utility's performance. Benchmarks are either absolute or relative or even unitless [21]. Absolute benchmarks come in the form of per capita water use/day which is exact, while relative benchmarks manifest in the form of water conservation or reduction strategies like 30\% per capita water use reduction by 2014 . Unitless benchmarks such as ratios and percentages represent relative benchmarks and are often target values. According to Kunkel et al. [41] cited in [21], an example of an absolute water benchmark is the Infrastructure Leakage Index (ILI) which is defined as the ratio of yearly water losses during transmission and distribution to an estimated value of unavoidable leakage.

Whether termed performance indicators or standards or cost ratios or statistics or best practice guides, these are all benchmarks [57]. Thus, as governments and regulatory agencies continue to review the operational directives or regulations, older benchmarks become "not applicable" and require updating. It is a different case where organisations do not have existing benchmarks to measure their performance(s). In such cases, they need to create or develop new benchmarks becomes necessary.

\section{Performance Indicators/Key Performance Indicators}

In the opinion of ([63], p.3), PIs are the building blocks for any benchmarking strategy and constitute "quantitative, comparable measurements of a specific type of activity or output." Being an absolute measure of performance, PIs basically suggest or reveal areas "where performance might need to be investigated" ([57], p.11).Thus, they provide the needed 
Table 4 Major industrial water use KPIs and metrics, with their application descriptions

\begin{tabular}{|c|c|c|c|c|}
\hline KPI & $\begin{array}{l}\text { Metric } \\
\text { (unit) }\end{array}$ & What is it? & What does it reflect? & What is good? \\
\hline $\begin{array}{r}\text { Total water } \\
\text { (absolute) }\end{array}$ & $\mathrm{m}^{3}$ & Total water use on site. & $\begin{array}{l}\text { Total volume of water } \\
\text { consumed in any } \\
\text { given time period } \\
\text { (week, month or } \\
\text { year). }\end{array}$ & Low levels. \\
\hline $\begin{array}{l}\text { Total water } \\
\text { (relative to } \\
\text { production) }\end{array}$ & $\begin{array}{c}\mathrm{m}^{3} / \mathrm{t} \text { of } \\
\text { prod- } \\
\text { uct }\end{array}$ & Total water use on site. & $\begin{array}{l}\text { Total volume of water } \\
\text { consumed in any } \\
\text { given time period } \\
\text { (week, month or year) } \\
\text { per tonne product. }\end{array}$ & $\begin{array}{l}\text { Will depend on } \\
\text { particular product and } \\
\text { production related } \\
\text { water use. }\end{array}$ \\
\hline $\begin{array}{c}\text { Consumptive } \\
\text { water }\end{array}$ & $\mathrm{m}^{3}$ & $\begin{array}{l}\text { Total water use on site, } \\
\text { excluding cooling } \\
\text { water extracted and } \\
\text { returned to source. }\end{array}$ & $\begin{array}{l}\text { Volume of water } \\
\text { consumed in any } \\
\text { given time period } \\
\text { (week, month or } \\
\text { year). }\end{array}$ & Low levels. \\
\hline $\begin{array}{l}\text { Process water } \\
\text { (absolute) }\end{array}$ & $\mathrm{m}^{3}$ & $\begin{array}{l}\text { Water used in processing } \\
\text { operations, including } \\
\text { that used as a raw } \\
\text { material (ingredient). }\end{array}$ & $\begin{array}{l}\text { Volume of water used in } \\
\text { any given time period } \\
\text { (week, month or year) }\end{array}$ & Low levels. \\
\hline $\begin{array}{l}\text { Process } \\
\text { water(relat- } \\
\quad \text { ive to } \\
\text { production) }\end{array}$ & $\begin{array}{c}\mathrm{m}^{3} / \mathrm{t} \text { of } \\
\text { prod- } \\
\text { uct }\end{array}$ & $\begin{array}{l}\text { Water used in processing } \\
\text { operations (including } \\
\text { that used as a raw } \\
\text { material—ingredient) } \\
\text { per unit of product. }\end{array}$ & $\begin{array}{l}\text { Volume of water used in } \\
\text { any given time period } \\
\text { (week, month or year) } \\
\text { to produce a } \\
\text { normalised unit of } \\
\text { production. }\end{array}$ & $\begin{array}{l}\text { Will depend on } \\
\text { particular product and } \\
\text { production related } \\
\text { water use. }\end{array}$ \\
\hline $\begin{array}{r}\text { Cleaning } \\
\text { water }\end{array}$ & $\mathrm{m}^{3}$ & $\begin{array}{l}\text { Water used for cleaning } \\
\text { purposes. }\end{array}$ & $\begin{array}{l}\text { May be difficult to } \\
\text { determine as process } \\
\text { water is often used for } \\
\text { cleaning and sourced } \\
\text { from a number of } \\
\text { areas } \\
\text { (cleaning-in-place } \\
\text { (CIP), hoses, hygiene } \\
\text { stations) that are not } \\
\text { sub-metered. }\end{array}$ & $\begin{array}{l}\text { Low levels, generally } \\
\text { good. }\end{array}$ \\
\hline Cooling water & $\mathrm{m}^{3}$ & $\begin{array}{l}\text { Water used as a coolant } \\
\text { (where applicable). }\end{array}$ & $\begin{array}{l}\text { May be difficult to } \\
\text { determine as process } \\
\text { water may be used for } \\
\text { cooling and may not } \\
\text { be separately } \\
\text { sub-metered. }\end{array}$ & $\begin{array}{l}\text { Low levels generally } \\
\text { good. }\end{array}$ \\
\hline Water re-use & $\begin{array}{c}\% \text { (by } \\
\text { vol- } \\
\text { ume) }\end{array}$ & $\begin{array}{l}\text { Proportion of water } \\
\text { re-used on site (e.g. } \\
\text { hot process water } \\
\text { re-used for fluming } \\
\text { raw materials or for } \\
\text { cleaning) as a per- } \\
\text { centage of the total } \\
\text { water consumed. }\end{array}$ & $\begin{array}{l}\text { Level of water re-use } \\
\text { being achieved. }\end{array}$ & $\begin{array}{l}\text { High levels, good, but } \\
\text { could mask } \\
\text { inefficient processes } \\
\text { or practices leading to } \\
\text { excessive water use in } \\
\text { the first place. }\end{array}$ \\
\hline
\end{tabular}

Adapted from ([65], p.11). information on whether or not a performance assessment should be conducted on a utility. According to [2], performance indicators are measures of the efficiency and effectiveness of services by an undertaking that result from the combination of several variables. These variables according to the authors are data elements measured from the field or deduced from standards that can be combined into processing rules in order to define performance. Further, as contained in the report by ([64], p.9),"KPIs are financial and nonfinancial measures that can be used to help a business define and evaluate how successful it is, typically in terms of making progress towards its long-term organisational goals"... and these "KPIs are essential to any successful benchmarking campaign."

It is also worthy of note that the International Benchmarking Network for water and sanitation utilities 

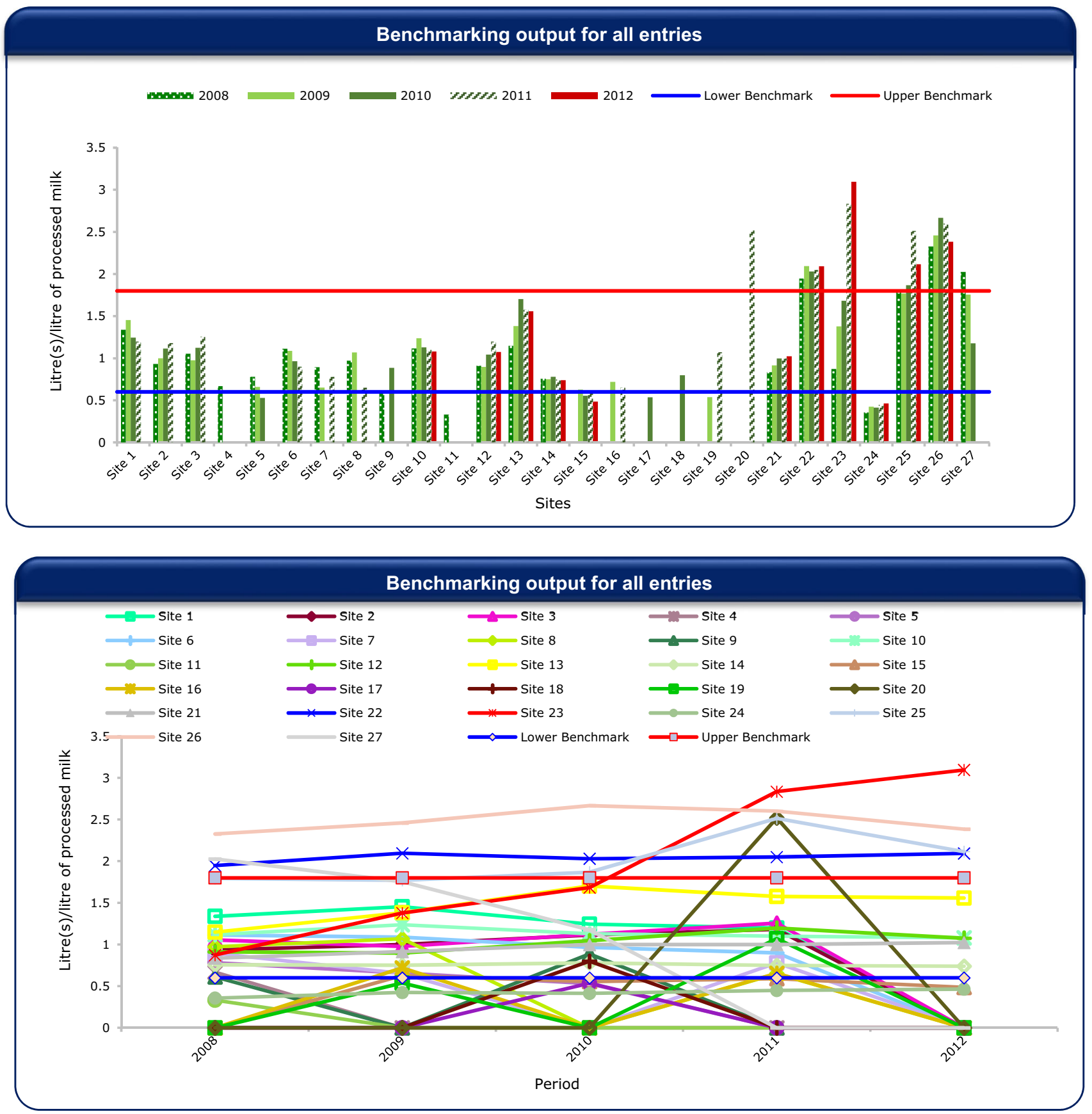

Fig. 2 Benchmarking results of water use for liquid milk production

(IBNET) developed a toolkit which provides a set of process, monetary and technical indicators, for assessing performance levels of water and wastewater services among utilities of different countries.

Performance indicators are very useful in metric benchmarking because as predetermined targets, they aid quantitative performance comparisons [42]; however, to examine business processes, the process benchmarking is best suited.

Although, Alegre et al. [2] have surmised that key PIs include water resources (WR), personnel (Pe), physical
$(\mathrm{Ph})$, operational (Op), quality of services (Qs), and economic and financial (EF), but these indicators do not provide the ratios or metrics for comparison. Against this milieu, ([39], p.270) gave a summary of water utilityKPIs that can be adopted for benchmarking comparison exercises as follows:

1. Average cost indicators (cost $/ \mathrm{m}^{3}$ of treated water)

2. Efficiency indicators (bills processed/staff/hour)

3. Time-related indicators (time to process a telephone enquiry) 
Table 5 Quantitative and economic water use performance results for the UK liquid milk production

\begin{tabular}{|c|c|c|c|c|c|c|c|c|c|}
\hline \multirow{2}{*}{$\begin{array}{l}\text { Site } \\
\text { Site } 1\end{array}$} & \multirow{2}{*}{\begin{tabular}{|l} 
Average water \\
use/unit Product
\end{tabular}} & \multirow{2}{*}{\begin{tabular}{|l} 
Rank \\
$1=$ Highest
\end{tabular}} & \multirow{2}{*}{ 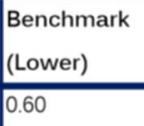 } & \multirow{2}{*}{\begin{tabular}{|l} 
Deviation \\
about Benchmark
\end{tabular}} & \multirow{2}{*}{\begin{tabular}{|l} 
Deviation \\
Value (\%)
\end{tabular}} & \multicolumn{2}{|c|}{$\begin{array}{l}\text { Water } \\
\text { charges }(£)\end{array}$} & \multicolumn{2}{|c|}{$\begin{array}{l}\text { Wastewater } \\
\text { charges (£) }\end{array}$} \\
\hline & & & & & & $£$ & 0.0011 & $£$ & 0.0010 \\
\hline Site 2 & 1.06 & 6 & 0.60 & 0.46 & $43.2 \%$ & $£$ & 0.0007 & $£$ & 0.0006 \\
\hline Site 3 & 1.10 & 5 & 0.60 & 0.50 & $45.6 \%$ & $£$ & 0.0008 & $£$ & 0.0007 \\
\hline Site 4 & 0.67 & 16 & 0.60 & 0.07 & $10.2 \%$ & E & 0.0001 & $£$ & 0.0001 \\
\hline Site 5 & 0.66 & 17 & 0.60 & 0.06 & $8.6 \%$ & $£$ & 0.0001 & $£$ & 0.0001 \\
\hline Site 6 & 1.02 & 8 & 0.60 & 0.42 & $41.0 \%$ & $£$ & 0.0007 & $£$ & 0.0006 \\
\hline Site 7 & 0.78 & 12 & 0.60 & 0.18 & $22.6 \%$ & $£$ & 0.0003 & $E$ & 0.0002 \\
\hline Site 8 & 0.90 & 9 & 0.60 & 0.30 & $33.1 \%$ & $£$ & 0.0005 & $£$ & 0.0004 \\
\hline Site 9 & 0.75 & 14 & 0.60 & 0.15 & $19.8 \%$ & $£$ & 0.0002 & $£$ & 0.0002 \\
\hline Site 10 & 1.13 & 4 & 0.60 & 0.53 & $47.1 \%$ & $E$ & 0.0008 & $£$ & 0.0007 \\
\hline Site 11 & 0.33 & 20 & 0.60 & -0.27 & $-80.1 \%$ & $-€$ & 0.0004 & $-€$ & 0.0004 \\
\hline Site 12 & 1.03 & 7 & 0.60 & 0.43 & $41.5 \%$ & $£$ & 0.0007 & $£$ & 0.0006 \\
\hline Site 13 & 1.47 & 2 & 0.60 & 0.87 & $59.3 \%$ & E & 0.0014 & $£$ & 0.0012 \\
\hline Site 14 & 0.76 & 13 & 0.60 & 0.16 & $20.6 \%$ & $£$ & 0.0002 & $£$ & 0.0002 \\
\hline Site 15 & 0.56 & 18 & 0.60 & -0.04 & $-6.3 \%$ & $-€$ & 0.0001 & $-€$ & 0.0000 \\
\hline Site 16 & 0.69 & 15 & 0.60 & 0.09 & $12.7 \%$ & $£$ & 0.0001 & $£$ & 0.0001 \\
\hline Site 17 & 0.54 & 19 & 0.60 & -0.06 & $-11.9 \%$ & $-€$ & 0.0001 & $-€$ & 0.0001 \\
\hline Site 18 & 0.80 & 11 & 0.60 & 0.20 & $24.8 \%$ & $£$ & 0.0003 & $£$ & 0.0003 \\
\hline Site 19 & 0.80 & 10 & 0.60 & 0.20 & $25.4 \%$ & $£$ & 0.0003 & $£$ & 0.0003 \\
\hline Site 20 & 2.52 & 1 & 0.60 & 1.92 & $76.2 \%$ & $£$ & 0.0030 & $£$ & 0.0026 \\
\hline
\end{tabular}

$\mathrm{Nb}$. If cells in the table above are highlighted in Red, then the corresponding sites use water above the average

4. Quality of service indicators (availability, quality of water, pressure)

5. Explanatory factors (scale of operation, inherited assets)

Further, [64] produced a summary of the key industrial water use KPIs, their corresponding units (metrics) and concise description of their application strategies (see Table 4).

In practice, water usage is quantified based either on total volume or in terms of production, that is, normalised volume ([10], p.14). The total volume is often related to water use per period of time such as litres or $\mathrm{m}^{3}$ /annum. Normalised volume on the other hand is associated with water use per unit or per volume of product or output, e.g. $1 / 1$ or $\mathrm{m}^{3} / 1$ or $\mathrm{kg} / \mathrm{l}$.

\section{Benchmarking Using the Upper and Lower Water Limits (Benchmarks)}

The upper and lower water limits are points on the metric that are used to identify where an environmental concern may be low, average or high for that characteristic [33]. These water use limits are generally known as control limits or performance indicators. Industrial processes or products are expected to perform below the lower limits; however, to accommodate acceptable variations in factors that contribute to higher or lower water use, such as plant performance, operation procedures and operator competency, a higher water use limits are introduced. Companies with water use below the lower limits are considered to perform "excellently"; those using water between the lower and upper limits are considered to use water "averagely", while water use above the upper limits is considered as "poor".

Further, as explained in the literature review, process benchmarking is a qualitative assessment approach; this contrasts with the metric benchmarking which is quantitative. Suffice it then that not all companies carryout both the process and metric benchmarking exercises. Some, based on set goals, carry out one, leaving the other. Thus, in the industry, the effectiveness of organisations' operations, procedures or processes may be assessed using non-numeric or textual information-process benchmarking; whereas, the volumetric performance of organisations is analysed using quantitative datametric benchmarking. To this end, the analyses associated with this study cover only the quantitative aspect of the performance assessment, known as the metric benchmarking.

\section{Materials and Methods}

For the data analyses, data were sourced from 53 UK dairy companies for a 5-year ( $\mathrm{min}$ ) period. These collected data are only secondary data because they were carefully collected and 

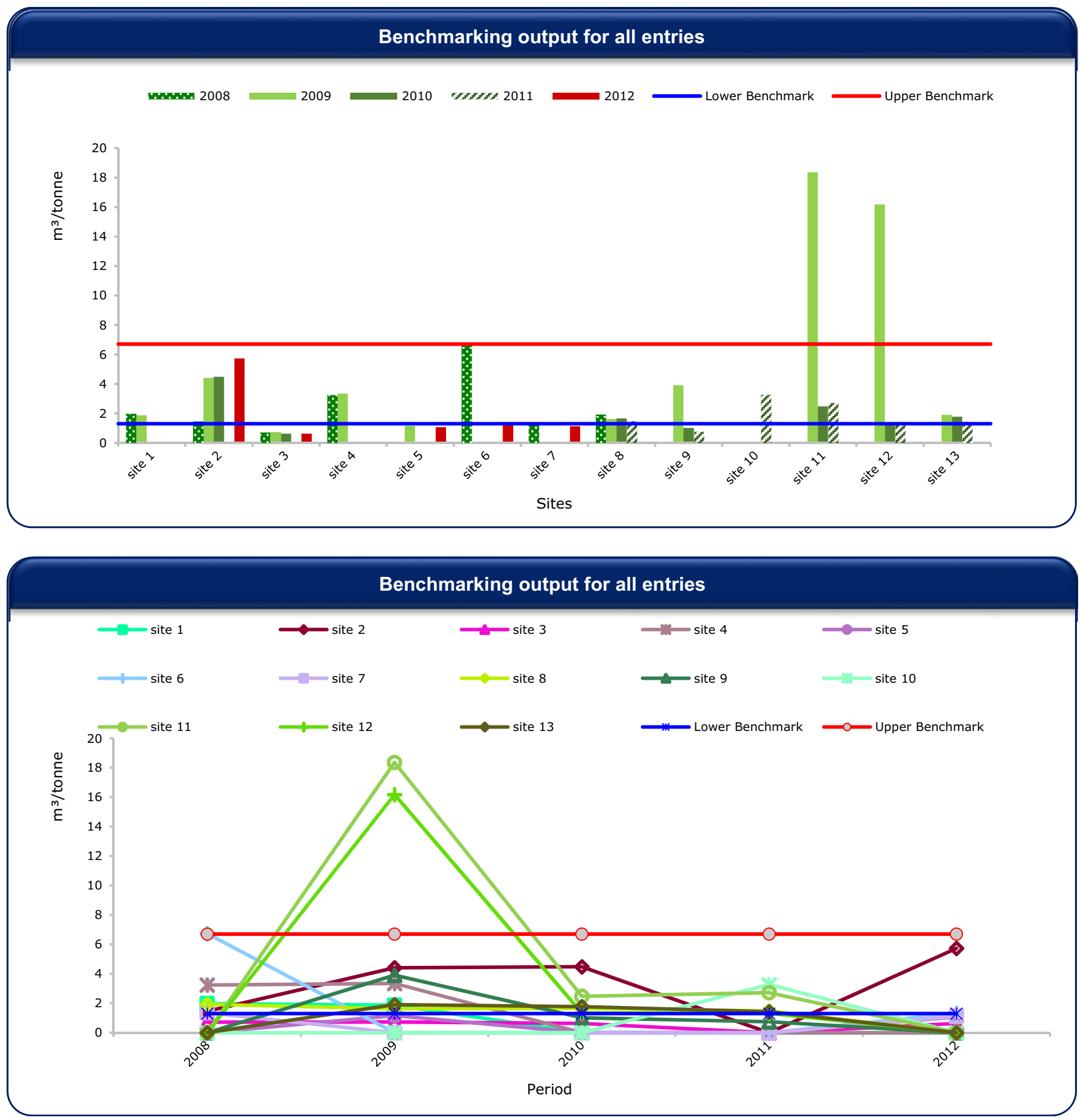

Fig. 3 Benchmarking results of water use for butter production

collated by the Dairy UK annually, and accessed for the data analyses of this study. More so, as the Dairy UK is a reputable trade body, data received from this sector is considered to be reliable. These data covered 27 liquid milk-producing companies, 13 butter- and 13 cheese-processing companies. In order to protect the companies' identities, data collected were anonymised; thus, the use of sites $1,2,3 \ldots$ site $n$. To conduct the data analysis, a benchmarking tool called " $i$-Water Benchmarking Tool", specifically developed for industrial water use assessment, was used. As revealed in Table 4, water use data are classified into either the normalised or total volume. This information enabled an accurate use of the benchmarking software. Thus, data used for the data analyses were exclusively normalised, and came in the form of $\mathrm{m}^{3}$ or litres/volume of product. Benchmarks used for this analysis were provided by $i$-Water Benchmarking Tool. The application filters the benchmarks to the least and most current benchmark for each process. The benchmark database of the tool is 
Table 6 Quantitative and economic water use performance results for UK butter production

\begin{tabular}{|c|c|c|c|c|c|c|c|}
\hline Site & $\begin{array}{l}\text { Average water } \\
\text { use/unit Product }\end{array}$ & $\begin{array}{l}\text { Rank } \\
1 \text { = Highest }\end{array}$ & $\begin{array}{l}\text { Benchmark } \\
\text { (Lower) }\end{array}$ & $\begin{array}{l}\text { Deviation } \\
\text { about Benchmark }\end{array}$ & \begin{tabular}{|l} 
Deviation \\
Value (\%)
\end{tabular} & $\begin{array}{l}\text { Water } \\
\text { charges (f) }\end{array}$ & $\begin{array}{l}\text { Wastewater } \\
\text { charges }(£)\end{array}$ \\
\hline site 1 & 1.92 & 7 & 1.30 & 0.62 & $32.3 \%$ & f $\quad 0.9851$ & f $\quad 0.8386$ \\
\hline site 2 & 4.02 & 4 & 1.30 & 2.72 & $67.6 \%$ & f $\quad 4.3142$ & \& $\quad 3.6724$ \\
\hline site 3 & 0.67 & 13 & 1.30 & -0.63 & $-93.3 \%$ & -f $\quad 0.9956$ & -f $\quad 0.8475$ \\
\hline site 4 & 3.29 & 5 & 1.30 & 1.99 & $60.5 \%$ & E $\quad 3.1595$ & \& 2.6894 \\
\hline site 5 & 1.11 & 12 & 1.30 & -0.19 & $-16.8 \%$ & $\begin{array}{ll}-£ & 0.2965\end{array}$ & -£ $\quad 0.2523$ \\
\hline site 6 & 4.03 & 3 & 1.30 & 2.73 & $67.7 \%$ & \& $\quad 4.3329$ & f 3.6883 \\
\hline site 7 & 1.24 & 11 & 1.30 & -0.06 & $-4.7 \%$ & $\begin{array}{ll}-\AA & 0.0929\end{array}$ & -E $\quad 0.0791$ \\
\hline site 8 & 1.67 & 10 & 1.30 & 0.37 & $22.2 \%$ & f $\quad 0.5889$ & f $\quad 0.5013$ \\
\hline site 9 & 1.89 & 8 & 1.30 & 0.59 & $31.2 \%$ & \& $\quad 0.9357$ & \& 0.7965 \\
\hline site 10 & 3.27 & 6 & 1.30 & 1.97 & $60.2 \%$ & \& $\quad 3.1186$ & \& 2.6547 \\
\hline site 11 & 7.85 & 1 & 1.30 & 6.55 & $83.4 \%$ & f $\quad 10.3886$ & f $\quad 8.8431$ \\
\hline site 12 & 6.27 & 2 & 1.30 & 4.97 & $79.3 \%$ & \& 7.8932 & \& $\quad 6.7189$ \\
\hline site 13 & 1.70 & 9 & 1.30 & 0.40 & $23.5 \%$ & f $\quad 0.6336$ & f $\quad 0.5394$ \\
\hline
\end{tabular}

$\mathrm{Nb}$. If cells in the table above are highlighted in Red, then the corresponding sites use water above the average

periodically updated by the developers. However, the benchmarks provided by the tool are first verified by comparing with benchmarks in literatures such as those contained in Table 3. As the assessment output, the tool eventually produces a graphical representation of the results as well as a tabular assessment of the economic performance of the companies benchmarked.

\section{Results and Discussion}

\section{Water Use Benchmarking for Liquid Milk Production}

$\mathrm{Nb}$. If cells in the table above are highlighted in red, then the corresponding sites use water above the average.

Figure 2 and Table 5 reveal the benchmarking results of performance comparison among 27 liquid milk production companies. From the first graph (benchmarking output for all entries), it is seen that sites 20-27 use water beyond the upper benchmark limit. In addition, Table 5 clearly reveals the ranked water use and economic performance of the benchmarked sites. From the assessment, it is seen that only sites 11,15 and 17 use water for liquid milk production excellently, water use by sites 20-27 is rated as "poor", while other sites' use of water is considered as "average". Based on the results, it is inferred that these poorly performing sites have greater potentials for water savings in their productions.

\section{Water Use Benchmarking for Butter Production}

$\mathrm{Nb}$. If cells in the table above are highlighted in red, then the corresponding sites use water above the average.

Figure 3 and Table 6 constitute the outcome of the benchmarking exercise on water use for the production of butter in the UK. It is seen that out of the 13 benchmarked sites, sites 3, 5 and 7 use water excellently; sites 1, 2, 4, 6, 8, 10 and 13 use water averagely, while sites 11 and 12 use water poorly. The benchmarks used for this analysis are contained in Table 3. Looking at the higher water consumption rate of sites 11 and $12\left(7.85 \mathrm{~m}^{3} / \mathrm{t}\right.$ and $6.27 \mathrm{~m}^{3} / \mathrm{t}$, respectively), relative to the $1.3 \mathrm{~m}^{3} / \mathrm{t}$ benchmark, it is most likely that these companies are unaware that they are using water intensively, thus the need for benchmarking. 

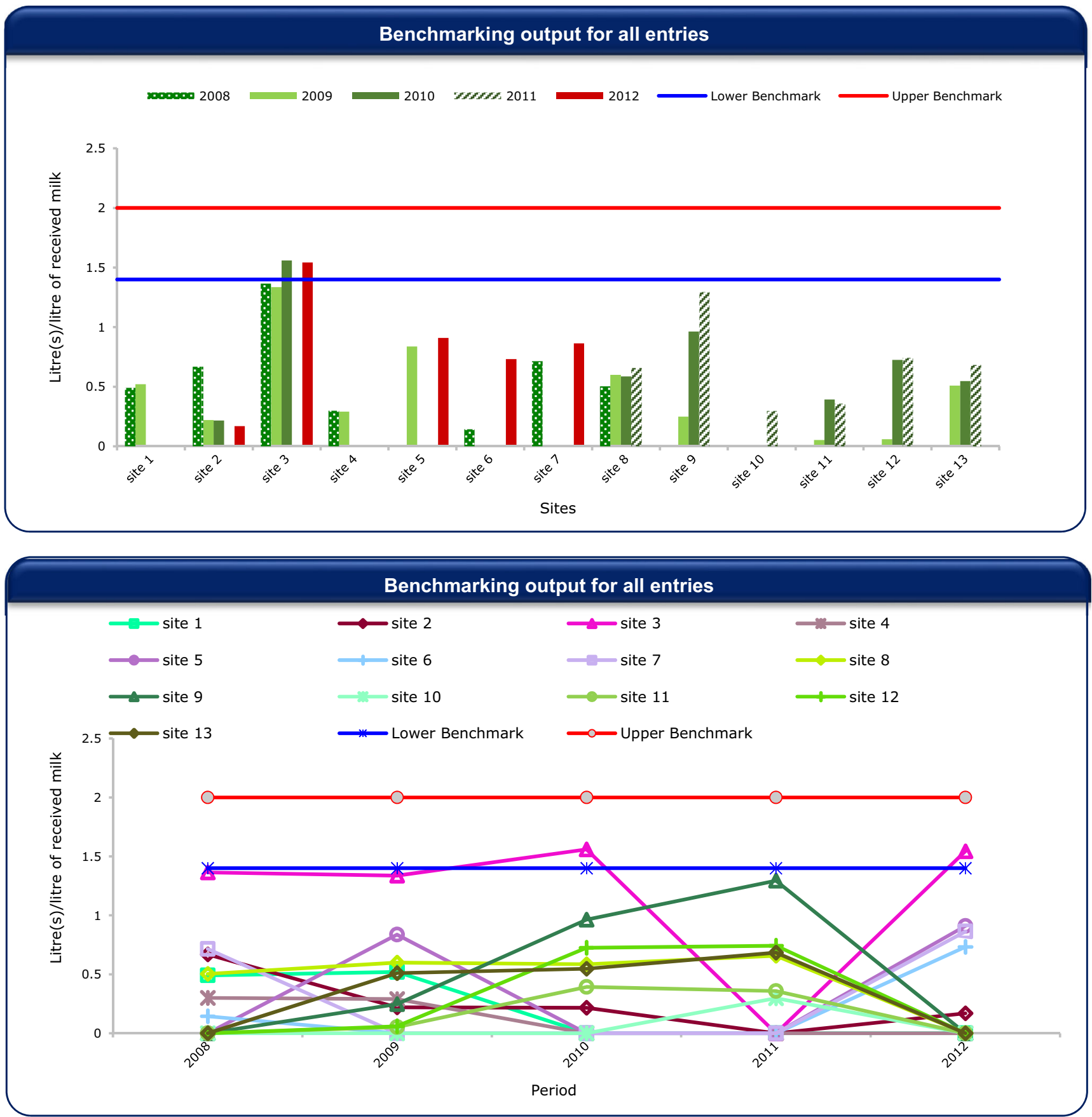

Fig. 4 Benchmarking results of water use for cheese production

\section{Water Use Benchmarking for Cheese Production}

$\mathrm{Nb}$. If cells in the table above are highlighted in red, then the corresponding sites use water above the average.

Results shown in Fig. 4 and Table 7 reveal that some dairy sites in the UK use water for cheese production "excellently". Also, the lower limit of 1.41 of water/litre of milk (as contained in the benchmarking tool) is consistent with the provision of [61] of $1.3 \mathrm{l} / \mathrm{kg}$ of milk lower limit and $4 \mathrm{l} / \mathrm{kg}$ of milk upper limit.
It can be seen from Table 7 above that only site 3 uses water "averagely". However, looking at the trend chart for the "benchmarking output for all entries", site 3's water use was below the $1.4 \mathrm{l} /$ litre of milk processed (lower benchmark) in 2008 and 2009, then it rose above this threshold in 2010, before eventually dropping below the $1.4 \mathrm{l} /$ /itre of processed milk, in 2011. It is important for site 3 to strive towards further reducing its water use below the lower benchmark in order to ensure that the water use trend does not go beyond the upper benchmark in subsequent years. 
Table 7 Quantitative and economic water use performance results for the UK cheese production

\begin{tabular}{|c|c|c|c|c|c|c|c|c|}
\hline Site & $\begin{array}{l}\text { Average water } \\
\text { use/unit Product }\end{array}$ & $\begin{array}{l}\text { Rank } \\
1=\text { Highest }\end{array}$ & $\begin{array}{l}\text { Benchmark } \\
\text { (Lower) }\end{array}$ & $\begin{array}{l}\text { Deviation } \\
\text { about Benchmark }\end{array}$ & $\begin{array}{l}\text { Deviation } \\
\text { Value (\%) }\end{array}$ & & r es $(E)$ & $\begin{array}{l}\text { Wastewater } \\
\text { charges }(£)\end{array}$ \\
\hline site 1 & 0.51 & 8 & 1.40 & -0.89 & $-176.7 \%$ & $-f$ & 0.0014 & $\begin{array}{ll}-£ & 0.0012\end{array}$ \\
\hline site 2 & 0.32 & 10 & 1.40 & -1.08 & $-339.2 \%$ & $-\varepsilon$ & 0.0017 & -£ $\quad 0.0015$ \\
\hline site 3 & 1.45 & 1 & 1.40 & 0.05 & $3.5 \%$ & $E$ & 0.0001 & E $\quad 0.0001$ \\
\hline site 4 & 0.30 & 12 & 1.40 & -1.10 & $-374.3 \%$ & $-£$ & 0.0018 & -£ $\quad 0.0015$ \\
\hline site 5 & 0.87 & 2 & 1.40 & -0.53 & $-60.2 \%$ & $-£$ & 0.0008 & $\begin{array}{ll}-£ & 0.0007\end{array}$ \\
\hline site 6 & 0.44 & 9 & 1.40 & -0.96 & $-219.4 \%$ & $-\varepsilon$ & 0.0015 & $\begin{array}{ll}-£ & 0.0013\end{array}$ \\
\hline site 7 & 0.79 & 4 & 1.40 & -0.61 & $-77.4 \%$ & $-\varepsilon$ & 0.0010 & $\begin{array}{ll}-£ & 0.0008\end{array}$ \\
\hline site 8 & 0.59 & 5 & 1.40 & -0.81 & $-138.7 \%$ & $-\varepsilon$ & 0.0013 & $-£ \quad 0.0011$ \\
\hline site 9 & 0.84 & 3 & 1.40 & -0.56 & $-67.5 \%$ & $-£$ & 0.0009 & $-£ \quad 0.0008$ \\
\hline site 10 & 0.30 & 11 & 1.40 & -1.10 & $-370.7 \%$ & $-£$ & 0.0017 & $\begin{array}{ll}-£ & 0.0015\end{array}$ \\
\hline site 11 & 0.27 & 13 & 1.40 & -1.13 & $-422.5 \%$ & $-£$ & 0.0018 & -£ $\quad 0.0015$ \\
\hline site 12 & 0.51 & 7 & 1.40 & -0.89 & $-175.0 \%$ & $-\varepsilon$ & 0.0014 & -£ $\quad 0.0012$ \\
\hline site 13 & 0.58 & 6 & 1.40 & -0.82 & $-141.2 \%$ & $-£$ & 0.0013 & -£ $\quad 0.0011$ \\
\hline
\end{tabular}

$\mathrm{Nb}$. If cells in the table above are highlighted in Red, then the corresponding sites use water above the average

\section{UK Dairy Sector Water Use Benchmarking Findings}

From the analyses of this study, benchmarking of the liquid milk companies revealed that during the 5 years under review, site 5 saved 0.781 of water/litre of milk produced, while site 15 consumed an additional 0.51 of water/litre of milk produced. In addition, for the assessment of water used in butter production, it was deduced that during same 5-year period, while site 2 consumed as much as $4.28 \mathrm{~m}^{3}$ of water/tonne of butter produced, site 6 saved $5.41 \mathrm{~m}^{3}$ of water/tonne of same product produced. Lastly, for the cheese production, over $90 \%$ of the sites used water above the upper water benchmark limit during the 5 years under consideration. From the analysis, site 9 consumed an additional 1.30 1/litre of received milk while site 2 saved 0.51 of water/litre of received milk.

\section{Conclusion}

Whereas, given the complex nature of the industrial sector and the difficulty associated with collecting data on water use by the industrial subsectors, very few researches on water use by industry have been published; yet, none of these limited publications is on benchmarking of water use in the industrial sector. Ultimately, the aim of every benchmarking process is to improve performance through comparison of an organisation's performance against those of high-performing comparable organisations or performance standards, and adapting of established best practices. Thus, this study set out to assess various dairy subsectors' use water, in terms of their water use per unit of the product. The use of normalised data (per unit product) is considered the most effective way of assessing the volumetric use of the freshwater resource. Data sourced covered the entire UK dairy and came from major dairy companies.

Further, of the 27 benchmarked liquid milk sites, only three sites use water below the minimum benchmark. It is also established that there is a relatively increasing trend in water use on most of the accessed sites. Unfortunately, there is currently no periodic benchmarking of the entire data of the Dairy UK across years that could be sent back to the concerned companies to reflect their performance, relative to other anonymised sites or benchmarks. From the assessment of the water use for manufacturing butter, though majority of the sites use water averagely and excellently, two sites' water use, in 2009, tripled the upper benchmark. It is considered that the companies must have applied some water conservation strategies in the following years that led to a sharp drop in 
their water use below averages. For the assessment of water use in cheese production, only one site used water above the lower benchmark. Based on this impressive performance result, it is considered that majority of the assessed companies have some form of water conservation scheme(s) in place. As revealed by The Federation House Commitment, as at March 2014, 70 signatories across 284 active sites had signed up to the commitment of reducing their water use by 2030 against a 2007 baseline, ([29]).

These findings serve as an indicator of how the UK Dairy sector is performing, relative to the United Nation's 2030 Vision, Goal 6, Target 4, which states that "by 2030 , substantially increase water-use efficiency across all sectors and ensure sustainable withdrawals and supply of freshwater to address water scarcity and substantially reduce the number of people suffering from water scarcity" [62]. It is clear from the result of this assessment, that majority (over 60\%) of the assessed Dairy UK sites use water inefficiently; this could be traced to the limited use or application of water efficient systems and processes, and inadequate periodic benchmarking of sites' performance. Thus, there is great potentials for water use improvements on the failing sites.

Based on the findings of this study, it is recommended that the Dairy UK sites adopt more water efficient systems and processes, and annually conduct benchmarking exercises, with the intention of helping the sites know how they are performing against their peers and benchmarking standards.

Open Access This article is distributed under the terms of the Creative Commons Attribution 4.0 International License (http:// creativecommons.org/licenses/by/4.0/), which permits unrestricted use, distribution, and reproduction in any medium, provided you give appropriate credit to the original author(s) and the source, provide a link to the Creative Commons license, and indicate if changes were made.

\section{References}

1. Agriculture and Horticulture Development Board (2015) Effective use of water on dairy farms [online] available: http://dairy.ahdb.org. uk/media/10351/effectiveuseofwaterondairyfarms.pdf. Accessed 3 Mar 2016

2. Alegre H, Baptista MJ, Cabrera E Jr, Cubillo F, Duarte P, Hirner W, Merkel W, Parena R (2006) Performance indicators for water supply services, 2nd edn. IWA Publishing, London

3. Alstete WJ (1995) "Benchmarking in higher education: adapting best practices to improve quality", ASHE-ERIC, Higher Education Report No. 5, The George Washington University, 141

4. Appleby A (1999) Benchmarking theory a framework for the business world as a context for its application in higher education. In: Smith H, Armstrong M, Brown S (eds) Benchmarking and Threshold Standards. Kogan Page, London

5. Atimtay AT, Subhas SK (2011) Security of industrial water supply and management. Springer Science+Business Media, Dordrecht. https://doi.org/10.1007/978-94-007-1805-0
6. Baker C, Bate A (2016) Dairy industry in the UK: Statistics, UK House of Commons BRIEFING PAPER Number 2721, 20 January 2016, [online], available: http://researchbriefings.files.parliament. uk/documents/SN02721/SN02721.pdf. Accessed 08 Mar 2016

7. Baker W, Tremolet S (1999) Industrial water pricing in OECD countries, France: Organisation for Economic Co-Operation and Development, 57, [online], available: http://search.oecd.org/ officialdocuments/displaydocumentpdf $/$ ? doclanguage $=$ en $\&$ cote $=$ env/epoc/geei(98)10/final. Accessed 13 Nov 2013

8. Bartholomai A (1987) Food factories: processes, equipment, costs. VCH Publishers, Inc., New York

9. Baumann BD (2011) Water conservation issues - introduction to water supply and conservation planning, [online], available: opensiuc.lib.siu.edu/cgi/viewcontent.cgi?article=1476\&context= jcwre. Accessed 08 May 2014

10. Beverage Industry Environmental Roundtable (2011) A practical perspective on water accounting in the beverage sector [online], available: http://www.waterfootprint.org/Reports/BIER-2011WaterAccountingSectorPerspective.pdf. Accessed 21 Mar 2015

11. Bosteels T, Tipping N, Botten C, Tippet M (2010) Sustainability benchmarking toolkit for commercial buildings: principles for best practice, [online] available: http://www.betterbuildingspartnership. co.uk/download/bbp benchmarking paper final.pdf. Accessed 12 Dec 2013

12. Cabrera E Jr, Arregui F, Cobacho R, Trull O (2002) Practical application of metric benchmarking in water supply systems. Water Supply 2(4):173-180

13. Cabrera E, Dane P, Haskins S, Theuretzbacher-Fritz H (2011) Benchmarking water services: guiding water utilities to excellence. IWA Publishing, London

14. Camp RC (1989) Benchmarking: the search for industry best practices that lead to superior performance. ASQ Quality Press, Wisconsin

15. Cross R, Iqbal A (1995) The rank Xerox experience: benchmarking ten years on. In: Benchmarking - theory and practice, Springer, New York, pp 3-10, available: https://ink.springer.com/content/ pdf/10.1007/978-0-387-34847-6_1.pdf. Accessed 20 June 2017

16. David EL (1990) Trends and associated factors in off stream water use: manufacturing and mining water use in the United States, 1954-83, USGS National Water Summary 1987-Water Supply and Use. Water Supply Paper 2350. Washington, D.C.: U.S. Government Printing Office, 81-92

17. Department for Environment Food and Rural Affairs (2007) Resource use efficiency in food chains: priorities for water, energy and waste opportunities [online], available: http://sciencesearch. defra.gov.uk/Document.aspx? Document=WU0103 4830 FRA. pdf. Accessed 26 Mar 2015

18. Department for Environment Food and Rural Affairs (2008) Future water: the government's water strategy for England [online], available: https://www.gov.uk/government/uploads/system/uploads/ attachment data/file/69346/pb13562-future-water-080204.pdf. Accessed 09 Jul 2015

19. Department for Environment, Food and Rural Affairs (2012) Waste water treatment in the United Kingdom: implementation of the European Union Urban Waste Water Treatment Directive - 91/ 271/EEC [online], available: https://www.gov.uk/government/ uploads/system/uploads/attachment data/file/69592/pb13811waste-water-2012.pdf. Accessed 4 Dec 2013

20. Department of Environmental Science and Technology (2012) The volumetric water consumption of British milk production, [online], available: http://dairy.ahdb.org.uk/non_umbraco/download.aspx? media $=16704$. Accessed 01 Mar 2015

21. Dziegielewski B, Kiefer JC (2010) Appropriate design and evaluation of water use and conservation metrics and benchmarks. Am Water Works Assoc J [online] 102(6):66-80 available: www.awwa. $\underline{\text { org/publications/journal-awwa/abstract/articleid/24 } \overline{576 / \text { issueid/ }}}$ 
33569333.aspx? getfile=/documents/dcdfiles/24576/waternet. 0072065.pdf [accessed 22 March 2015]

22. Ellis M, Dillich S, Margolis N (2001) Industrial Water Use and its Energy Implications [online], US Dept of Energy, Office of Energy Efficiency and Renewable Energy, Washington, DC, available: http://aceee.org/files/proceedings/2001/data/papers/SS01 Panel1 Paper03.pdf. Accessed 13 May 2014

23. Environment Agency (2002) "Probability distributions for long period rainfall: a scoping study", R \& D Technical Report W6-065/TR

24. Environment Agency (2003) Optimum use of water for industry and agriculture: phase 3, Best Practice Manual, R\&D Technical Report W6-056/TR2 [online], available: https://www.gov.uk/ government/uploads/system/uploads/attachment data/file/290549/ sw6-056-tr2-e-e.pdf. Accessed 13 May 2014

25. Environment Agency (2013) Food and drink manufacturing water demand projections to 2050, Main Report - EBPLW12033 [online], available: https://www.gov.uk/government/uploads/system/ uploads/attachment data/file/297233/LIT 8767 4d1fe5.pdf. Accessed 3 June 2014

26. Environmental Technology Best Practice Programme (1998) Reducing the cost of cleaning in the food and drink industry, GG 154 Guide, [online], available: http://infohouse.p2ric.org/ref/23/ 22893.pdf. Accessed 08 Mar 2016

27. Environmental Technology Best Practice Programme (1999) Reducing Waste for Profit in the Dairy Industry, Guide GG242

28. European Environment Agency (1999) Sustainable water use in Europe: part 1 -sectoral use of water, Environmental Assessment Report No.1 [online], available: http://www.eea.europa.eu/ publications/binaryeenviasses $01 \mathrm{pdf} /$ download. Accessed 30 Nov 2013

29. Federation House Commitment (2013) The Federation House Commitment Progress Report 2013 [online] available: http:// www.wrap.org.uk/system/files/private/Federation\%20House\% 20Commitment\%20Progress\%20Report\%202013.pdf. Accessed 08 June 2014

30. Food Industry Sustainability Strategy (2007) Report of the food industry sustainability strategy champions' group on water. Department for Environment, Food and Rural Affairs, London

31. Harris D (1984) Dairy design for practical reductions in energy and water operating costs. Institution of Chemical Engineers Symposium Series (84 (Profitability of food processing)): 193-206

32. Holt CP, Phillips PS, Bates MP (2000) Analysis of the role of waste minimisation clubs in reducing industrial water demand in the UK. Res Conserv Recycl [online] 30(4):315-331, available: http://www. sciencedirect.com/science/article/pii/S0921344900000689 [accessed 13 November 2013]. https://doi.org/10.1016/S09213449(00)00068-9

33. International Maritime Organization (2009) London convention and protocol guidance for the development of action lists and action levels for dredged material. International Maritime Organization, London

34. Jackson NL (1998a) Understanding standards-based quality assurance Part 11: nuts and bolts of the Dearing policy framework. Quality Assurance in Education 6:220-231

35. Jackson NJ (1998b) Introduction to benchmarking assessment practice. In: Jackson N (ed) Pilot Studies in Benchmarking Assessment Practice in UK Higher Education. Quality Assurance Agency for Higher Education, Gloucester

36. Jackson N (2001) Benchmarking in UK HE: an overview. Qual Assur Educ [online] 9(4):218-235, available: http://search. proquest.com.proxy.idp.gcu.ac.uk/docview $\overline{213732635 /}$ fulltextPDF/1426BB3A3CC75ABDEB/20?accountid=15977 [accessed 18 November 2013]. https://doi.org/10.1108/ 09684880110411955

37. Jackson NJ, Lund H (2000) Introduction to benchmarking. In: Jackson N, Lund H (eds) Benchmarking for Higher Education. Open University Press, Buckingham
38. Kelessidis V (2000) Benchmarking, Report produced for the EC funded project. Thessaloniki Technology Park, Greece

39. Kingdom W (1998) Use of performance indicators and performance benchmarking in the North American water industry-findings from studies recently completed for AWWA and WEF Research Foundations. Aqua: J Water Supply Res Technol 47(6): 269-274

40. Kumar R, Robins N (1999) Producing, providing, trading: manufacturing industry and sustainable cities. Environ Urban [online] 11(2):75-94 available: eau.sagepub.com/content/11/2/75.full. pdf [accessed 27 November 2013]

41. Kunkel KE, Easterling DR, Redmond K, Hubbard K (2003) Temporal variations of extreme precipitation events in the United States: 1895-2000. Geophysical Research Letters:30. https://doi. org/10.1029/2003GL018052

42. Larsson M, Parena R, Smeets E, Troquet I (2002) Process benchmarking in the water industry: towards a worldwide approach. IWA Publishing, London

43. Love R, Bunney H, Smith M, Dale B (1998) Benchmarking in water supply services: the lessons learnt. Benchmark Qual Manag Technol 5(1):59-70

44. North Carolina Cooperative Extension Service (1996) Liquid assets for your dairy plant. Water Quality and Waste Management.

45. Paralez LL (1999) Utility benchmarking on the west coast. Am Water Works Assoc J [online] 91(11):65-71

46. Price I (1994) A plain person's guide to benchmarking. Special report of the unit for facilities management research. Sheffield Hallam University, Sheffield

47. Rad SJ, Lewis MJ (2014) Water utilisation, energy utilisation and waste water management in the dairy industry: a review. Int J Dairy Technol 67(1):1-20. https://doi.org/10.1111/1471-0307.12096

48. Renzetti S, Dupont PD (2003) The value of water in manufacturing, CSERGE Working Paper ECM 03-03 [online], Brock University, Department of Economics, Ontario, available: http:// prototype2010.cserge.webapp3.uea.ac.uk/sites/default/files/ecm 2003 03.pdf. Accessed 2 Nov 2013

49. Reynaud A (2003) An econometric estimation of industrial water demand in France. Environ Resour Econ [online] 25(2):213-232 available: http://link.springer.com/content/pdf/10.1023/A: 1023992322236.pdf [accessed 13 November 2013]

50. Robertson S, Inc K, Consulting Engineers (1989) Water and WasteWater Management in the Dairy Industry (Natsurv 4), prepared for the Water Research Commission, WRC Project No 145, TT38/89

51. Schofield A (1998) Benchmarking an overview of approaches and issues in implementation. In: Schofield A (ed) Benchmarking in Higher Education: An International Review. CHEMS, London and UNESCO, Paris, 7-20

52. Scottish Water (2012) Submission from Scottish water [online] available: http://www.scottish.parliament.uk/S4 LocalGovernmentandRegenerationCommittee/General\% 20Documents/Scottish Water submission.pdf. Accessed 12 Dec 2013

53. Seneviratne M (2007) A practical approach to water conservation for commercial and industrial facilities. Elsevier Ltd, Oxford, p 300

54. Simpson M, Kondouli D (2000) A practical approach to benchmarking in three service industries. Total Qual Manag 11(4-6):623-630. https://doi.org/10.1080/09544120050007977

55. Spendolini MJ (1992) The benchmarking book, 2nd edn. Amacom, New York

56. Suvio P (2011) From threat to an asset: water in steelworks. How modern steelworks can improve water related performance via benchmarking and development of high density sludge (HDS) process [online], unpublished $\mathrm{PhD}$ thesis Cardiff University, available: http://orca.cf.ac.uk/26204/1/2012SuvioPEngD.pdf. Accessed 6 Dec 2013 
57. The Chartered Institute of Public Finance ad Accountancy (1996) Benchmarking to improve performance. CIPFA, London

58. The Federation House Commitment (2012) Progress Report: 2012 [online] available: https://www.fdf.org.uk/industry/FHC_2012 annual report web.pdf. Accessed 2 Mar 2016

59. The Institute of Grocery Distribution (2007) Water use in the supply chain [online], available: http://www.igd.com/our-expertise/ Sustainability/Water/3403/Water-Use-in-the-Supply-Chain/. Accessed 09 Feb 2014

60. The UK government (1992) Competition and Service (Utilities) Act 1992: water supply and sewerage services, [online]available: http:// www.legislation.gov.uk/ukpga/1992/43/section/39. Accessed 16 Oct 2016

61. United Nations Environment Programme \& Danish Environmental Protection Agency (2000) Cleaner production assessment in dairy processing [online] available: http://www.unep.fr/shared/ publications/pdf/2480-CpDairy.pdf. Accessed 5 Mar 2016
62. United Nations (2010) \#Envision2030 Goal 6: Clean Water and Sanitation [online] available: https://www.un.org/development/ desa/disabilities/envision2030-goal6.html. Accessed 17 Sept 2017

63. Van den Berg C, Danilenko A (2011) The IBNET water supply and sanitation performance blue book: the international benchmarking network of water and sanitation utilities databook. World Bank Publications, Washington DC

64. Waste and Resources Action Programme (2013) Water use in the UK food and drink industry [online], available: http://www.wrap. org.uk/system/files/private/Technical\%20report\%20-\%20Water\% 20use $\% 20$ in $\% 20$ the $\% 20$ food $\% 20$ and $\% 20$ drink $\% 20$ industry 1. pdf. Accessed 20 Feb 2013

65. Waste and Resources Action Programme (2014) Federation House Commitment Progress Report 2014 [online], available: http://www. fhc2020.co.uk/fhc/cms/fhc-annual-report-2014. Accessed 19 Feb 2015 